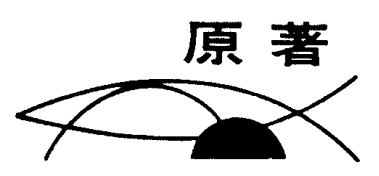

\title{
ネブライザの微生物污染防止之適正使用法
}

\author{
勝 井 則 明* 真 鍋 美 智子*2 \\ 喜 多 英 二*
}

\section{Microbial Decontamination of Nebulizers and Their Proper Use}

\author{
Noriaki Katsui* ${ }^{*}$ Michiko Manabe ${ }^{* 2}$ and \\ Eiji Kita \\ * Department of Bacteriology, Nara Medical University \\ *2 Azwell Inc.
}

\begin{abstract}
Nebulizers have been recognized as potential agents of nosocomial respiratory infection. In this study, ultrasonic and jet nebulizers were evaluated for their relative hazard as measured by the concentration of bacterial output delivered with the aerosol and the contaminant counts of components of the nebulizers. Reservoirs were seeded with a tracer organism Pseudomonas fluorescens $\left(\sim 10^{6} \mathrm{CFU} / \mathrm{ml}\right)$ in distilled water. Results indicate that the jet nebulizer produces heavily contaminated bacterial aerosols (urcountable colonies in the $10 \mathrm{sec}$ sampling period), whereas the ultrasonic nebulizer produces $135 \mathrm{CFU} /$ plate in the $60 \mathrm{sec}$. The contaminant counts of components of the jet nebulizer were $10^{2} \sim 10^{3}$ times higher than those of the ultrasonic nebulizer. When the contaminated corrugated and nasal tubes were used, the contaminants stayed on those tubes. And the use of the contaminated airfilter also gave identical results. The contamination due to the flow backwards of snivel or saliva from a nasal tube or a mouthpiece was protected by the back-flow valve. No viable organisms were detected in every component of the nebulizers after the disinfection with $0.1 \%$ Tego 51 for $15 \mathrm{~min}$ at room temperature.

\section{1. 目 的}

ネブライザ (吸入器) は現在の医療において 呼吸器疾患の吸入療法に欠かせない医療機器で あり，また気道への加湿を目的としても広く使 用されている。しかし，ネブライザには薬液あ るいは生理食塩水等の液体を使用するため, 微

* 奈良県立医科大学 細菌学教室

*2(侏)アズウェル

生物污染を受けやすいという問題点がある。污 染されたネブライザから発生する粒径数 $\mu \mathrm{m}$ のエアロゾルには污染微生物が含まれるため, ネブライザ使用者に呼吸器感染を引き起こす危 険性がある。特に，感染に対する抵抗力の低下 した患者，いわゆる易感染患者の場合には，通 常の抵抗性を有する者には問題にならないよう な微生物によって惹起される感染（日和見感染） が問題となるため, ネブライザの微生物污染は, それが特に病原性の強い微生物でなくても, 院




\section{( 2 ) 医器学 Vol. 70, No.7 (2000)}

内感染における重要な医原性因子となり得る.

欧米では既に1960年代よりネブライザによる 院内感染の危険性が指摘され，污染の実状およ び感染例屯多数報告されている ${ }^{1)}$. わが国でも, ネブライザの微生物污染が原因で 4 名が死亡し た重大な院内感染例が報告されているが2)，ま だまだネブライザの微生物污染の危険性に対す る認識が不十分で，医療現場において十分な注 意が払われているとは言い難い。また，污染防 止のために何らかの対策を立てようとしても， 国内ではこれまで污染の実状調查や効果的な対 策の研究は極めて少なく，ネブライザの取り扱 いに関する適切な情報が得にくい現状である。

著者らはこれまで，ネブライザの微生物污染 に関する文献を集積・整理し，院内感染例，污 染微生物の種類および污染対策等についてまと めた ${ }^{1)}$ 他, 病院内で使用中のネブライザの微生 物污染調查や管理方法の分析を行い，污染を低 減するための取り扱い方法を提案してきた ${ }^{3)}$.

本研究では, 現在使用されているネブライザの 主流である超音波式およびジェット式について, ネブライザを人為的に細菌污染させて各種の実 験を行い，ネブライザの使用に当たって有用之 思われる若干の知見を得たので報告する.

\section{2. 方 法}

\section{1）使用ネブライザ}

実験には，4種類のネブライザ A：アズウェ ル UN-701， B : アズウェル AZ-11， C: アズ ウェル 日商式吸入用コンプレッサセット，D： オムロン NE-C11を用いた。 ネブライザAは超 音波式， $\mathrm{B} ， \mathrm{C}, \mathrm{D}$ はジェット式である.

超音波式ネブライザの原理を図 1-aに示した。 水槽は 2 重構造になっており，内側の水槽（薬 液槽）に吸入液を入れる. 外側の水槽（作用槽） には水道水もしくは蒸留水を入れ，取り付けて ある超音波振動子を作動させると，その振動が ダイアフラムを介して薬液槽に伝播し，槽内の 吸入液がェアロゾル化する，そこへ送風ファン によりェアフィルタを通過させた空気を送り込 み，エアロゾルを外部に送り出す，実験に用い たネブライザ A では，薬液槽に長さ $80 \mathrm{~cm}$ の蛇 管が連結し，蛇管の他端にはマウスピースが接

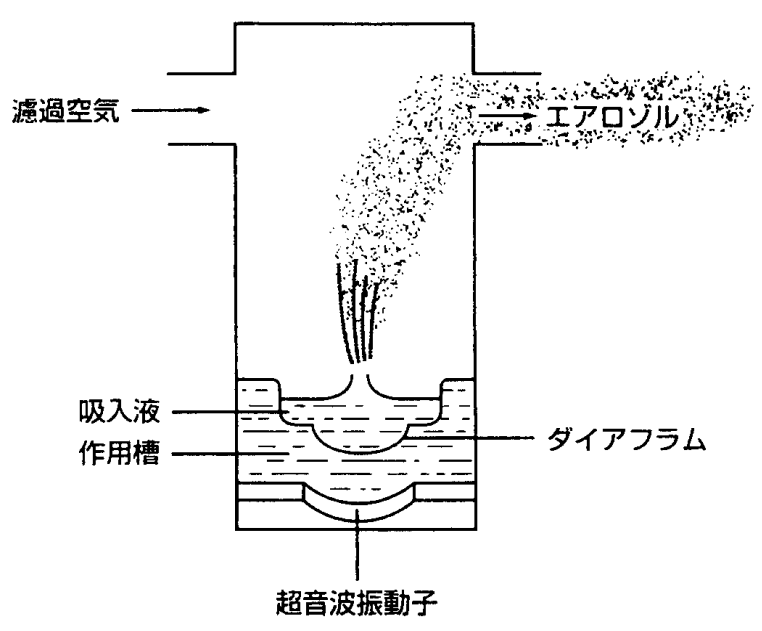

図 1-a＼cjkstart超音波式ネブライザの原理

続している.

ジェット式ネブライザの原理は霧吹きと同じ で (図 1-b)，コンプレッサによりエアフィル 夕を通過させた空気を薬液槽に送り込み, ベル ヌーイの原理により吸入液をエアロゾル化して 外部に送り出すものである．実験に用いたネブ ライザ B，Dではネブライザ本体（薬液槽）に 霧化ハウジングが，そして霧化ハウジングには マウスピースが連結している．また，ネブライ ザCはネブライザ本体（形状は図 1-b に相当） だけでも使用されるが，本実験ではネブライザ 本体に曲管とよばれるガラス管を，曲管にはさ らに鼻管を取り付けて実験を行った。なお，ネ ブライザ B， C，Dには蛇管は使用していない。

\section{2）供試菌および菌液の調製}

本実験では, 供試菌として Pseudomonas fluorescens IID 5115 を使用した. この菌を 選択したのは，ネブライザの污染菌として

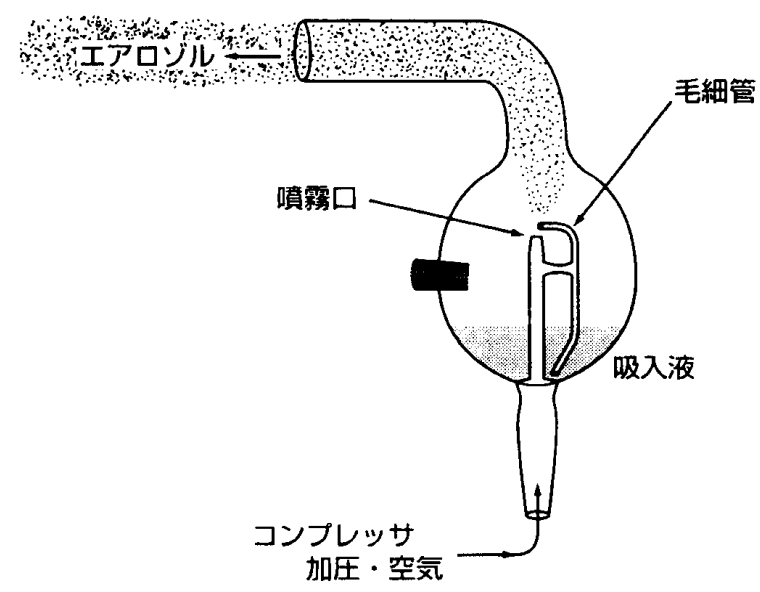

図 1-b ジェット式ネブライザの原理 
Pseudomonas spp. が最あ一般的なあのの一 つであること ${ }^{133}$ ，および実験中に菌が室内に 飛散する場合があるため, 安全性を考慮してバ イオセイフティレベルが 1 であることを基準 としたためである。菌は Tryptic Soy Broth （Difco）で $30^{\circ} \mathrm{C} \cdot 2$ 日間振盪培養を行った後, 無菌水で 1 回洗浄し，同液にて適当な菌濃度に 希釈したものを実験に供した.

なお，3.3）項「蛇管・鼻管加らの污染菌飛散 の有無」の実験では, Staphylococcus aureus IID 1677 （MRSA）む使用した，菌液の調製方 法は, P. fluorescens の場合とほぼ同様で，培 養温度は $37^{\circ} \mathrm{C}$, 培養時間は 24 時間とした。

\section{3）細菌污染試験および消妻}

消毒・洗浄・乾燥した清潔なネブライザ（オー トクレーブ可能な部品はオートクレーブ処理を した）の薬液槽に前記 2.で述べたように調製 した菌液を入れ，エアロゾル発生量を最大とな るようにセットして装置を15分間作動させた。

実験中のエアロゾル発生量は装置作動前後の重 量を測定して計算した。エアロゾル中の生菌数 測定には Tryptic Soy Agar プレートをエア ロゾル噴出口から $5 \mathrm{~cm}$ の位置に立て掛け，一 定時間培地表面にエアロゾルを噴霧した。装置 停止後, ネブライザ部品を取り外し，無菌水 10 $\mathrm{m} l$ (蛇管の場合は $50 \mathrm{~m} l$ ) で各部品の内壁を繰 り返し洗浄し，污染菌を洗い出した．洗浄液中 に含まれる生菌数を測定することにより，ネブ ライザ部品の污染菌数を求めた．各サンプルの
生菌数測定にはそれぞれ 3 枚の Tryptic Soy Agar プレートを使用し， $30^{\circ} \mathrm{C} て ゙ 24 〜 36$ 時間培 養後, コロニ一数を测定して平均值を求めた。

ネブライザの消毒には，両性界面活性剤のテ ゴー51（〔株】アズウェル）を用いた。取り外 した各部品を $0.1 \%$ \%゙ー 51 に 15 分間常温にて 浸漬し，その後，水道水の流水中にて十分に洗 浄した．各部品の消毒後の生残菌についても， 上記と同様にして検出した。 また，ネブライザ $\mathrm{A}$ の各部品については残留消毒剂をニンヒドリ ン発色法により定量した。なお，その他の実験 の“方法”については, 次項に記載した。

\section{3. 結果}

\section{1）細菌污染試験および消毒効果}

薬液槽内に: P. fluorescens の $10^{6} \mathrm{CFU} / \mathrm{m} l$ レベルの菌液を入れ，ネブライザを作動させた。 この菌濃度にこれまでに報告されているネブラ イザの微生物污染の高いレベルに相当する数值 である11. 污染試験の結果を表1に示した。工 アロゾル中の生菌数は，超音波式では培地への 噴霧時間が60秒間で $135 \mathrm{CFU/plate}$ であった のに対して，ジェット式では噴霧時間を10秒間 と短くして屯測定できない多数のコロニーが検 出されたままた，部品の污染菌数を比較すると， 超音波式ではマウスピースの污染菌数は $10^{3}$ CFUレベルに対して，ジェット式ではマウス ピースや霧化ハウジング等の污染菌数は $10^{5}$ 〜 $10^{6} \mathrm{CFU}$ レベルの著しく高い数值を示した.

表 1 ネブライザの細菌污染試験

\begin{tabular}{|c|c|c|c|c|}
\hline \multirow{2}{*}{ ネブライザ } & 超音波式 & \multicolumn{3}{|c|}{ ジェット式 } \\
\hline & $\mathrm{A}$ & $\mathrm{B}$ & $C$ & $\mathrm{D}$ \\
\hline $\begin{array}{c}\text { エアロソル発生量 } \\
\text { (ml/min) }\end{array}$ & 1.33 & 0.50 & 0.29 & 0.46 \\
\hline 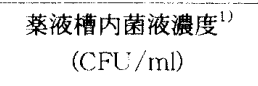 & $1.4 \times 10^{6}$ & $2.5 \times 10^{6}$ & $1.1 \times 10^{6}$ & $1.9 \times 10^{6}$ \\
\hline $\begin{array}{c}\text { エアロソル中の生菌数 } \\
\text { (CFU/plate) }\end{array}$ & $\begin{array}{c}135 \\
\text { (測定時間 } 60 \mathrm{sec})\end{array}$ & $\begin{array}{c}\mathrm{UC}^{2\}} \\
\text { (測定時間 10sec) }\end{array}$ & $\begin{array}{c}\text { UC } \\
\text { (測定時閆 } 10 \mathrm{sec} \text { ) }\end{array}$ & $\begin{array}{c}\text { UC } \\
\text { (測定時間 } 10 \mathrm{sec} \text { ) }\end{array}$ \\
\hline $\begin{array}{c}\text { 部品の活染菌数 } \\
(\mathrm{CFU}, \text { 但し蛇管 } \\
\text { のみCFU/cm) }\end{array}$ & $\begin{array}{c}\text { マウスピース : } 2.0 \times 10^{3} \\
\text { 蛇管 : } 9.4 \times 10^{2}\end{array}$ & $\begin{array}{c}\text { マウスピースス: } 4.4 \times 10^{5} \\
\text { 荡化ハウジング: } 1.4 \times 10^{6}\end{array}$ & $\begin{array}{l}\text { 舜管: } 2.4 \times 10^{5} \\
\text { 曲管: } 1.1 \times 10^{5}\end{array}$ & $\begin{array}{l}\text { マウスピース: } 4.0 \times 10^{5} \\
\text { 雺化ハウジング: } 2.2 \times 10^{6}\end{array}$ \\
\hline $\begin{array}{c}\text { 消毒後 }{ }^{3)} \text { の部品の } \\
\text { 生残菌 }\end{array}$ & 末検出 & 未検出 & 未柃出 & 未検出 \\
\hline
\end{tabular}

1) 使用菌株: Pseudomonas fluorescens IID 5115

${ }^{2)}$ UC : uncountable, コロニーが多過ぎて測定不可

${ }^{3)}$ 消毒条件：0.1\%テゴー51に常温で 15 min 浸渍後、水道水で洗浄 
ネブライザ使用後の各污染部品を $0.1 \%$ \%デー 51 に常温で15分間浸漬後，水道水にて洗浄した 結果，超音波式およびジェット式とも，いずれ の部品からも生残菌は検出されなかった。 また, ネブライザAの部品については残留消毒㶡の量 を調べたが，いずれの部品についても検出限界 （5ppm）以下であった。

\section{2）蛇管による飛散菌減少の効果}

ネブライザから発生するエアロゾル中に含ま れる菌数は, 超音波式に比べてジェット式では 著しく高い值となったが（表1），その要因の一 つとして蛇管の有無が考えられる．即ち，エア ロゾルが蛇管を通過中に，污染菌を含んだ大き なエアロゾル粒子が蛇管の壁面に付着して除去 される可能性がある. そこで, ジェット式ネブ ライザに蛇管を連結することにより，エアロゾ ル中に含まれる菌数が減少するかどうかを調べ た。実験はジェット式ネブライザBの霧化ハウ ジングとマウスピースの間にネブライザ Aの蛇 管を連結して行った。 $1.0 \times 10^{4} \mathrm{CFU} / \mathrm{m} l$ の菌 液を薬液槽に入れてネブライザを作動させた。 エアロゾルの培地への噴霧時間を30秒間として 測定した結果，蛇管のない場合は73CFU/plate であったのに対し，蛇管を取り付けた場合には $15 \mathrm{CFU} /$ plate と約 1/3に減少した（図2）。

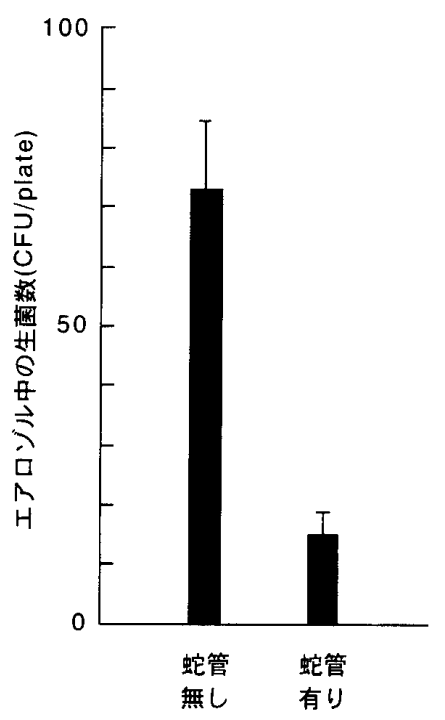

図 2 蛇管による飛散菌減少の効果

\section{3）蛇管・管からの污染菌飛散の有無}

蛇管や鼻管などェアロゾルが通過する部品が 污染されている場合，それらから污染菌が外部 に飛散するかどうかを超音波式ネブライザAに
ついて調べた。 P. fluorescens の高濃度菌液 $\left(2.7 \times 10^{9} \mathrm{CFU} / \mathrm{m} l\right)$ を調製し，蛇管之鼻管に それぞれ $10 \mathrm{~m} l$ および $0.4 \mathrm{~m} l$ を入れ，内壁を よく濡らした，ネブライザAの清潔な薬液槽に 無菌水を入れた後，この污染された蛇管と鼻管 を連結してネブライザを作動させ，エアロゾル 中の菌数を調べた。この実験では，培地への噴 霧時間を10分間と長くとったが，コロニーは検 出されなかった。 また，MRSA（菌濃度 $1.7 \times$ $\left.10^{8} \mathrm{CFU} / \mathrm{m} l\right)$ を用いて同様の実験を行ったが, この場合にもエアロゾル中から菌は検出されな かった. したがって，蛇管や鼻管が污染されて いても，それらから污染菌が飛散する可能性は 少ないと考えられた。

\section{4）逆流防止管の効果}

ネブライザの使用に際し，鼻管やマウスピー スを使用した場合，鼻汁や唾液が逆流して楽液 槽に入ると，エアロゾル中に鼻汁や唾液中の菌 が含まれることになる，たとえそれらの菌が自 己の保有菌であっても，異所性感染を起こす可 能性がある。このような事態を防止するために, 逆流防止管（図 3）が使用されるが，その効果 について調べた。ジェット式ネブライザBの霧 化ハウジングに逆流防止管と鼻管を連結し, 鼻 管加 P. fluorescens の高濃度菌液 $\left(3.2 \times 10^{8}\right.$ $\mathrm{CFU} / \mathrm{m} l)$ を $1 \mathrm{~m} l$ 注入した。鼻管を通過した 菌液は逆流防止管内に貯留した。この状態で, 清潔な薬液槽に無菌水を入れた後，ネブライザ を作動させ，エアロゾル中の菌数を調べた。こ の実験でも，培地への噴霧時間を10分間と長く とったが，コロニーは検出されず，逆流防止管 の有用性が認められた。

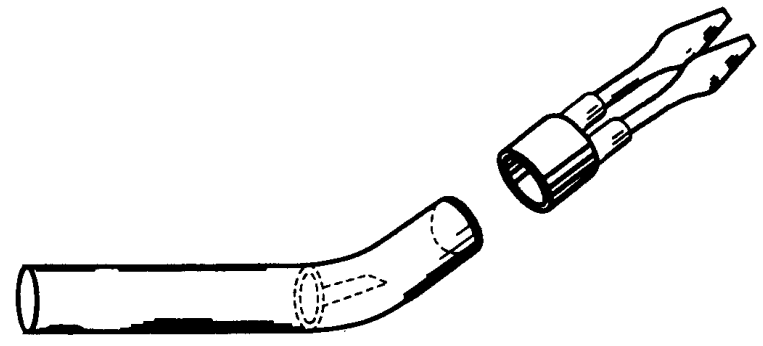

図 3 逆流防止管および鼻管

5）エアフィルタからの污染菌飛散の有無

ネブライザに取り付けてあるエアフィルタが 污染されている場合，そこから污染微生物が飛 
散するかどうかを調べた。数年間病院で使用し たAと同型のネブライザから污染されたエアフィ ルタを取り外し，清潔なネブライザAに取り付 けた。 薬液槽に無菌水を入れて装置を作動させ, エアロゾル中に污染菌が含まれるかどうかを調 べた。この奉験でも，培地への噴霧時間を10分 間と長くとって調べたが，コロニーは検出され なかった。したがって，エアフィル夕が污染さ れていても，そこから污染微生物が飛散する可 能性は少ないと考えられた。ただし，污染フィ ルタを使用した場合, 空気の流量が低下するた め, エアロゾル噴霧量の減少が認められた。な お, 使用したエアフィルタの污染菌数を調べた ところ $37 \mathrm{CFU} / \mathrm{cm}^{2}$ で, 形成されたコロニー の形態的性状から判断すると, 真菌が $2 / 3$ で, 細菌が $1 / 3$ の割合であった。

\section{4. 考察}

本研究では, 現在使用されているネブライザ の主流である超音波式およびジェット式につい て，ネブライザを人為的に細菌污染させて各種 の実験を行った，表 1 に示したように，ネブラ イザのエアロゾル中に含まれる菌数は超音波式 (A) に比べて, ジェット式（B，C，D）の方 が著しく高い值を示した。 また, 部品の污染菌 数も, 部品の形状が異なるので一概には言えな いが、ジェット式の方が $10^{2} \sim 10^{3}$ 倍高くなった。 その要因としては, 蛇管の有無, エアロゾル発 生量, エアロゾルの流速, およびェアロゾルの 粒径が考えられる，まず，蛇管については，超 音波式ネブライザ $\mathrm{A} に は$ 長さ $80 \mathrm{~cm}$ の蛇管が取 り付けてあるのに対し，ジェット式ネブライザ B， C，D にはない. 蛇管が取り付けてある場 合, エアロゾルが蛇管を通過中に，細菌を含ん だ大きなエアロゾル粒子が蛇管の壁面に付着し て除去される可能性が考えられる. そこで, ジェッ ト式ネブライザBに蛇管を取り付けて実験を行 ったところ，エアロゾル中の菌数が約 $1 / 3$ に減 少した（図 2). しかしながら，表1に示した ジェット式と超音波式のエアロゾル中の菌数の 違いは極めて大きく，蛇管の有無だけでは説明 しきれない. 次に, エアロゾル発生量について は表 1 に示したように，ジェット式の方が超音
波式より少ない值であるため，要因とは考えら れない，また，エアロゾルの流速であるが，こ れはエアロゾル発生量に必ずしも比例するもの ではなく，エアロゾルが通過する経路の形状に より異なってくる，今回の実験で用いたエアロ ゾル中の菌数測定法では, 培地表面に噴霧され るエアロゾルの流速が速いほど, 污染菌が培地 表面に付着しやすいことが予想される. 今回の 実験条件とほぼ同条件で，エアロゾル噴出口よ り $2 \mathrm{~cm}$ の位置におけるエアロゾルの流速を流速 計 (KANOMAX CLIMOMASTER 型式 6511, NIHON KAGAKU KOGYO CO. LTD) を用 いて測定した[株〕アズウェルにおける実験結果 によると, 超音波式ネブライザ A では約 $25 \mathrm{~m} /$ sec であったのに対し，ジェット式ネブライザ B，C，Dではそれぞれ $6 \sim 8,5 \sim 10,2.0$ $2.2 \mathrm{~m} / \mathrm{sec}$ 但い值を示した。したがって，エア ロゾルの流速も要因とは考えにくい. 最後に, エアロゾルの粒径であるが, レーザ光回折法に より焦点距離 $100 \mathrm{~mm}$ でェアロゾルの粒径を 測定した結果では，超音波式ネブライザ Aでは 体面積平均径 (SMD; Sauter Mean Diameter) が 4 5 $\mu \mathrm{m}$ であるのに対し，ジェット式ネブラ イザ B，Cでは 5 6 $6 \mu \mathrm{m}$ であると報告されてい $ろ^{4)}$. それぞれの平均粒径を 4.5 および $5.5 \mu \mathrm{m}$ と仮定すると，その体積比はジェット式は超音 波式の 1.8 倍以上となり，それだけエアロゾル 中に污染微生物を包含しやすくなると考えられ る.したがって, 以上の考察より, 今回の実験 結果における超音波式とジェット式ネブライザ のエアロゾル中およびネブライザ部品の污染菌 数の相違の要因としては，エアロゾルの粒径の 違い, および蛇管の有無が示唆された.

ネブライザの消毒方法としては，消毒剤の使 用, ガス殺菌，加熱殺菌等が報告されている ${ }^{1}$. 今回の実験では両性界面活性剂のテゴー51を使 用したが, 各部品はかなりの菌濃度で污染され ていたにもかかわらず，消毒後はいずれの部品 からも生残菌は検出されず，十分な殺菌効果が 認められた。 また, 消毒後の洗浄む, 水道水で 十分にすすぐことにより, 残留消毒剤は検出限 界以下にまで低減した。今回使用した消毒剤は 特に強力な消毒剤ではないので, 他の消毒方法 


\section{(6) 医器学 Vol. 70, No.7 (2000)}

であっても，適切な操作を行えば，同様の効果 が得られるあのと予想される。

污染された蛇管や鼻管からの污染菌の飛散実 験では，かなり高濃度の菌で污染させたにもか かわらず，菌の飛散は認められなかった。した がって, 単にエアロゾルが通過するだけの部品 では，それらから污染菌の飛散は起こりにくい と考えられる. 更えろん，人体に接触して使用 する鼻管やマウスピースの污染は, 付着菌が直 接人体に感染することがあるので注意が必要で ある。なお，鼻管やマウスピースからの鼻汁や 唾液の逆流による污染については, 蛇管を使用 している場合には, 鼻汁や陲液が薬液槽にまで 入る可能性は低いが，今回の実験で用いたジェッ ト式ネブライザのように蛇管を使用しないタイ プのものは，薬液槽と鼻管あるいはマウスピー スとの距離が短いため, 鼻汁や唾液が薬液槽に まで入り易い，このような污染は逆流防止管に より防ぐことができるので, 必要に応じて使用 するのが望ましい。

また, 污染されたエアフィルタの使用につい ても, エアフィルタからの污染菌の飛散は認め られなかった。 したがって, 微生物污染防止の 観点からは，エアフィルタの交換を頻繁に行う 必要性は低いと考えられるが, エアフィルタの 污染に伴って空気の流量が低下し，エアロゾル 噴霧量が減少するため，その点での定期的な交 換は必要である。

本研究をまとめると，ネブライザによる院内 感染を防止するためには，エアロゾル発生部位 である薬液槽の消毒, ならびに人体と直接接触 する鼻管やマウスピース等の末端部品の消毒 が，ネブライザの管理上最も重要と考えられる. 最後に，ネブライザで使用する吸入液自体が污 染されていれば，ネブライザ装置の消毒をいく ら完璧に行っても意味がないのは言うまでもな い. 尾家ら51, 病院内で使用されている吸入 液の多くが $10^{2} \sim 10^{6} \mathrm{CFU} / \mathrm{m}$ ルレベルのP Peudomonas spp. や Serratia marcescens などによ る污染を受けていると報告している. また,こ れまでの院内感染例の報告でも, ほぼ半数が吸
入液の污染に原因があったとされている1)。し たがって，ネブライザの使用に当たっては, 吸 入液の污染防止についてもネブライザ装置と同 等の十分な注意を払う必要がある。

\section{5. 結 論}

1）ジェット式ネブライザは，超音波式ネブ ライザに比べて, エアロゾル中の污染菌および ネブライザ各部品の污染菌数とも著しく高い值 を示した，その要因として，エアロゾルの粒径 の相違および蛇管の有無が示唆された。

2）エアロゾルが通過するだけの部品（蛇管, 鼻管等）は，それらが污染されていても，そこ からの污染菌の飛散は認められなかった。 また, エアフィルタからの污染菌の飛散も認められな かった。

3）鼻管やマウスピースからの鼻汁や唾液の 逆流による污染は, 逆流防止管により防ぐこと ができる.

4）ネブライザの污染部品を $0.1 \%$ デー 51 に 常温で15分間浸漬後，いずれの部品からも生残 菌は検出されなかった。

\section{文献}

1) 勝井則明, 加藤信行, 浅田祥司 : ネブライザー による院内感染とその対策，防菌防徽，26（6）: 321-326, 1998.

2) Takigawa, K., Fujita, J., Negayama, K. et al. : Nosocomial outbreak of Pseudomonas cepacia respiratory infection in immunocompromised patients associated with contaminated nebulizer devices, J. Jpn. Ass. Infect. Dis., 67 (11) : 1115-1125, 1993.

3）勝井則明, 柳生善彦, 田中二見ほか：病院内で 使用中のネブライザーの微生物污染とその対策, 防菌防徵, 23 (6) : 329-333, 1995.

4）株式会社アズウェル“ネスコジェット AZ-11” パンフレット（1999年 4 月）.

5）尾家重治, 神谷 晃: 吸入療法に用いていた吸 入液の細菌污染, 防菌防徽, 21（5）:233-236, 1993. 